\title{
Stretching the Hypothetically "Unstretchable" Check against Boko Haram Terrorist Recalcitrance around the Lake Chad Basin Area: A Direct Payoff for Staking the State and State Interest on the Platter of Personal Attention
}

\author{
Mark Bolak Funteh* \\ PhD , Associate Professor, the University of Maroua, Cameroon, Africa
}

\author{
*Corresponding Author: Mark Bolak Funteh, PhD Associate Professor, the University of Maroua, \\ Cameroon, Africa.
}

\begin{abstract}
With the emergence and the scary inhumane actions perpetrated by the terrorist Islamic sect, Boko Haram (BH) around the Lake Chad Basin region, it was certain that checking and annihilating this group would be a matter of a short breath following the military might, war experience of and the security sustaining interest of the inhabitant states. But the massive individual and collective state deployments to bring the phenomenon to book seemed ineffective, hence prolonging the supposedly short fight against these terror belligerents. Many scholars attribute the protracted resistance of the sect to the "asymmetrical" nature of the war, but this assumption has been waved away by many observers and critics of the issue. New approaches to the understanding of why BH and its activities have stayed obstinate to the sophisticated international and local diplomatic and military moves have becomes unavoidable. This paper, written on the basis of published and unpublished sources - actors, observers and eyewitness's accounts for that matter is a grass-root dimensional endeavor to the question. It provides answer to the "why" and "how" questions of citizens' treachery penchant towards the noble course against terrorism.
\end{abstract}

Keywords: Stretch, hypothetically "unstretchable" check, terrorism, recalcitrance, direct payoff, stake, state interest, platter, personal Attention, Lake Chad Basin Area

\section{INTRODUCTION}

Talking about the state and the desire of sustaining the state interest is in itself talking about the interactive actions of inhabitants of, different identities/groups or not, within a collective polity called a nation-state, and their interest and readiness to respect and support its decision in the execution of its duties at all times. Papp (1988:18) and Davids (2003:26) make meaning of a state as a geographicallybounded recognized entity governed by a central authority with the ability to make laws, rules and decisions, and to reinforce them within its boundaries. It is legal, recognized under the international law as a fundamental decision-making unit of the international legal system. States are supposed to determine their own policies and establish their own forms of government, which may differ significantly from one state to the other, and from these define who amongst its inhabitants is a citizen. Regardless of their status, however, the inhabitants of the territory of a state are subject to the laws of that state. By contrast, a nation is not necessarily a geographically bounded or legally defined entity. It is more of a grouping of people who view themselves as being linked to each other in some manner recognized and upheld by them as their own, the reason why political theorists perceive it mostly as a psychological fixation than anything else. Hence, groupings of persons can be considered a nation if related either ethnically, culturally or linguistically. In some other sense, nations may exist without territorial control, as did the Jewish nation before the foundation of the Israeli state in 1948.

Of course, this brings to mind the concept of nationhood and patriotism. There are two contrasting paradigms that explain the development and origin of the nation, namely the modernist and ethnicist. The modernists see the nation and nationalism as phenomena whose roots do not extend beyond a period associated with the major socio-economic process of modernity such as industrialization, capitalism, the rise of the modern state and major related political changes, meanwhile the ethnicists hold that nationalism has its roots in pre-modern ethnic identities (Day and Thompson 2004: 46). 
Stretching the Hypothetically "Unstretchable" Check against Boko Haram Terrorist Recalcitrance around the Lake Chad Basin Area: A Direct Payoff for Staking the State and State Interest on the Platter of Personal Attention

Nixon (2003: 33) and Thompson (2000: 198) make reference to the Ukrainians in the former Soviet Union, the various Indian tribes in the United States of America in the same light, like Leopold who presents other groups calling themselves national liberation movements aimed at having territorial control in certain areas, thereby becoming a state. The Palestine Liberation Organisation in the Middle East, the Southwest Africa People's Organisation in the then Southwest Africa (Namibia), the Farabundo Marti National Liberation Front in El Salvador, The Bakassi Freedom Fighters of Southern Cameroons are examples of national liberation movements which seek to establish control in areas which are currently either part of another state, a colonial holding of another state or under control of a state government that the national liberation movement believes is oppressing its people. Osita Agbu (2004:12) cites the Conseil National pour la Défense de la Démocratie / Forces pour la Défense de la Démocratie in Burundi and the Forces Nationales de Libération formerly known as the Parti pour la Libération du Peuple Hutu, as well as other groups which fought against marginalisation by the Tutsis leadership for over a decade. In Chad, the Union des Forces pour la Démocratie et le Développement tried to topple Idriss Deby's government. The Uganda's Lord's Resistance Army is perhaps one of the oldest African rebel movements and the most regionalized, which for over the last two decades has been fighting the Museveni government.

More so, ethno-regional based governance, marginalization and exclusion, fermented separatist rebel movements such as the Sudan People's Liberation Movement/Army in Southern Sudan. The Tuareg rebellion in the northern parts of Mali and Niger, and South Algeria seeks an Azawad independent state (Clapham, 1998: 1-18). In the Casamance region of Senegal, the Mouvement des Forces Démocratiques de la Casamance has been waging a self-determination struggle since the 1980s. In Ethiopia, the Ogaden National Liberation fights the Ethiopian government for the control of the oilrich Ogaden region. And for the past seven years, the Islamic fundamentalist group, the $\mathrm{BH}$, championed by the transnational Kanuri ethno-religious group around the Lake Chad Basin area have been lousy with the desire to create an Islamic Caliphate. In fact, all of these groups represent and coordinate the spirit of nationalism in one way or the other; a feeling of attachment and a sense of pride in itself among members of the group. Such feelings become evident in a group when it feels politically, economically or socio-culturally frustrated or believed to be oppressed by another group within the same collective polity, and thus pose a real challenge to true patriotism and collectiveness. Some of their actions have been very expressive in the language of destruction of public and in some cases private properties and also in terms of dead-tolls records. The states within which these happen often resist them stiffly as a means of ensuring peace, security, harmony and collective being. In situations where neighbours share the threads of a common enemy, they all stood for one another until such was brought to book (Funteh, 2015 a: 166).

Consequently, the collectiveness of a polity represents not only state or a nation the sanctity by itself but must be able to stands the test of the nation-state appellation, or what I should call here the "spirit of the nation-state" where by all inhabitants consider themselves to be a nation and work in all effort to sustain the interest of that polity. In this way, a nation or state (as I interchangeably use them in this paper to stand for the same thing) is perceived to be a geographically bounded legal entity under a single government which the people psychologically consider to be in some way, shape or form related to it. Papp (1988: 19) claims that the term "nation-state is historically more recent than either state or nation and reflects the growing convergence in recent years between the two older terms". He maintains that countries today are often referred to as nation-states, even though in many instances they are not. In Africa for instance, the territory of many states that received independence during the 1950s and 1960s was based on what had been the old colonial boundaries. Thus in some instances, a state counts many nations (or ethnic or tribal entities) as it inhabitants, and in other instances a single nation because of the arbitration of old colonial manipulation and/or boundaries finds itself inhabiting several different states, or nation-states. This was exactly the case with Africa after independence when the OAU, as and respected by all, gave no room for any alternation of colonial boundaries (Funteh, 2015 b: 33).

No wonder, Davidson (1967: 43-48) says that the African colonial territories, which attained independence, cannot in a strict sense be regarded as nation-states. They do not embrace a common past; they are indeed the arbitrary creations of colonialism, leaving a heritage of artificially controlled 
Stretching the Hypothetically "Unstretchable" Check against Boko Haram Terrorist Recalcitrance around the Lake Chad Basin Area: A Direct Payoff for Staking the State and State Interest on the Platter of Personal Attention

borders that now demarcate the emerging African states, and serve as a source of conflict or insecurity among and within many African states. The Lake Chad Basin area remains a glaring example. For instance, Nigeria inhabits many groups with the Fulani and Hausa in the North, Yoruba, Berom at the centre, Yoruba in the west and southwest and the Ibos in the south and south east; the principal ethnic entities (Njoku, 2002:249). To make things worse these groups are divided into the Christians and the Moslems. This is also the case with Cameroon with close to 245 ethnic groups, shared amongst the large Grassfields, the Sawa, Bulu-Fang Beti and the Northern groups. Chad is not so different from these with over 200 ethnic groups; the Sara, Arab, Kanembu, Massa/Mussey/Musgum being the major ones. But what makes things worse is the dichotomy that exists between the Christian and the Muslim communities that characterize this basin area. In chad, the east, north and west follow Islam, and those of the south are mostly Christians and animists. In Cameroon, the Northern part is principally Moslem while the southern Christian despite the presence of animists in both areas. In Nigeria, What is more complicated in the whole story is the transnational posture of some ethnic group across the three countries in the area, like the Kanuri, Fulani and Hausa groups. Even with these, each nation has the obligation to respect its international boundaries. For, as Davidson (1992: 34) puts it, these boundaries were designed to reinforce an international system of absolute sovereignty of the state in which boundaries were derived from geo-military occupation of space as determined by consenting colonial powers. More than a century later, many of these territorial boundaries remained as they were drawn, and these international boundaries and "ideas behind them" still form the foundation for the present international legal system ${ }^{1}$ (McCorquodale and Pangalangan, 2001:1-2).

Within seventy years, virtually all of the colonies regained their independence, but many of them have been troubled by the legacy of trying to get two or more states to live peacefully in a single state; some of the ingredient of that peace being national unity, integration, cohesion and the responsibility to support of state actions. Thus, experiencing these within a collective polity between the different groups therein has been the desire of the state. But this appeared a great task for different governments at different historical periods, especially in Africa where the concepts of national cohesion and integration are found as tablets of policies per de juror rather than per de facto. These governments often desired to transfer the loyalty of the inhabitants of their state from old groups of identification to that of the new states, obliging them to feel and live together as a common people (Anderson, 1991 as cited by Davidson, 1992: 34). In short, cohesion and integration involve the creation of a very high degree of comprehensiveness. A polity is considered cohesive when it has effective control over the use of the means of violence; it has a center of decision making capable of effecting the allocation of resources and rewards and it is a dominant focus of political identification for a large majority of politically aware citizens. With integration, all citizens are to be committed to mutual programmes. They have to fulfill certain obligations that include to comply submissively with the constitutional order of the state and to participate in its defense from all perspectives. And during emergencies or wartime, citizens may be required to assume additional obligations in the interest of national security and public order.

\footnotetext{
${ }^{1}$ The primary components of the international legal system are states, and territorial boundaries are a key element in how states are defined by that system. While the boundaries determined by the system are often artificially created and contested, they exist by the operation of the system, which usually seeks to reinforce these boundaries and the concept of territorial sovereignty inherent in them. From this perspective, the purpose of territorial boundaries is to clarify which entities are states and to separate them from each other in order to structure that system. This is because at the basis of international law, lies the notion that a state occupies a definite part of the surface of the earth, within which it normally exercises jurisdiction over persons and things to the exclusion of the jurisdiction of other states. States are the representatives of the inhabitants of the territory, which must be a "permanent population", thus ethnicity, religion or moral practices become largely irrelevant as living space is determined by the state's territorial boundary. In this context, contrary is coterminous with sovereignty. The direct connection between territorial boundaries was made in 1910 by the Permanent Court of Arbitration. It was re-enforced by the International Legal Order that emerged after the World War II and recognized as fundamental purposes in the Charter of the United Nations as reaffirmed in the authoritative declaration of principles of international law, adopted by the UN General Assembly (see Anderson, 1991: 7-9).
} 
Stretching the Hypothetically "Unstretchable" Check against Boko Haram Terrorist Recalcitrance around the Lake Chad Basin Area: A Direct Payoff for Staking the State and State Interest on the Platter of Personal Attention

In as much as the citizen had an obligation of commitment, the state also had its own obligations, which was to safeguard its sovereignty and territorial integrity, and to provide security for its peoples. These range from guaranteeing territorial integrity, with external threats, use of military force, and the security of national borders to "any major security issues, including without limitations those of a political, strategic, economic, social, or ecological nature" (Henk, 2005: 32). Provision of security also includes "freedom from fear and freedom from want." In fact, this can be broadened into seven main areas, namely economic security, which necessitates access to employment and the earning of basic income on a sustained basis; food security (implying economic and physical access to food and balanced nutrition), health security that stands for access to health facilities, medical care and basic drugs. It also means protection from all forms of communicable and non-communicable diseases; environmental security (the protection of the environment and its natural resources upon which lives depend, though it also means exploiting natural resources in such a way as not to compromise its use by future generations); personal security (which stands for freedom from physical violence caused either by the state, groups or individuals. It also means freedom from threat to life, including suicide and drugs). This also includes the provision of personal security, to be guaranteed both at home and at the work place; community security, which means the freedom to belong to a community or communities, be they family, racial, religious, ethnic or others. Moreover, communities should be free from any forms of harassment, violence or intimidation. Political security is an inclusive element in the issue, which indicates clearly the freedom of the individual to hold particular political posts.

Thus, when each part does its assignment well, there is bound to be deliberate blend between the state and its citizens, the reign of peace or a collective reasoning and action towards the installation of peace and prosperity where need be. From all these, it can be noted that the principal interest of the African states is the protection of their sovereignty, territorial space, substance of integration, cohesion and peace within the collective polity, and of course uphold the spirit of belonging and patriotism among citizens. But this interest of the state was betrayed by its citizen during the fight against the terrorist group $\mathrm{BH}$, an incident that cost the state much in terms of time, human, technical and material efforts. The war estimated to last for a short while was not the case. So why would citizen betray their states and its interest in such a crucial period? How was this done? What are the lessons learned in this? These amongst other questions constitute this paper. This is the reason why the first part is a brief profile of the BH terrorist activities in the Lake Chad Basin Area and the individual and collective state efforts against these atrocities, the second looks at the citizens' betrayal of state interest in this honorable assignment of protecting its state from external enemies. The paper concludes with a therapeutic approach to such issues.

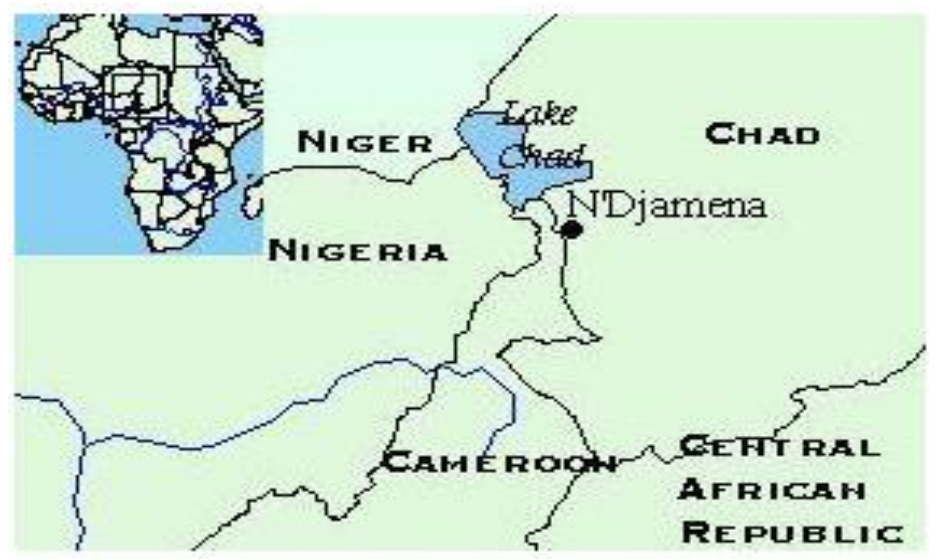

Map of Boko Haram Actions around the Lake Chad Basin Area

\section{BH Imprints across LAKe Chad Basin Region Versus State Individual ANd COLleCtive Checking STRATEgies: An EPIGRAMmatic Version}

For close to seven years now, the region of the Lake Chad Basin has undergone serious security challenges and breakdown perpetrated by this extremist Islamic sect. Interwoven in a geographic and historical immediacy the countries (Nigeria, Cameroon, Chad and Niger) in this region could not avoid being targets of this sect that grew out Nigeria's history of instability. 
Stretching the Hypothetically "Unstretchable" Check against Boko Haram Terrorist Recalcitrance around the Lake Chad Basin Area: A Direct Payoff for Staking the State and State Interest on the Platter of Personal Attention

In our paper (Funteh and Azieh, 2015) we, from in-depth investigations, show how BH grew out of a group of radical Islamist youths who worshipped at the Al-Haji Muhammadu Ndimi Mosque in Maiduguri, capital of Borno state, in the 1990s. Its leader, Mohammed Yusuf, began as a preacher and leader in the youth wing, Shababul Islam (Islamic Youth Vanguard), of Ahl-Sunnah, a Salafi group. His erstwhile mentor was Sheikh Jafaar Mahmud Adam, a prominent Islamic scholar and preacher at the mosque. Yusuf, charismatic and popular Malam (Quranic scholar) spoke widely throughout the north. His literal interpretation of the Quran led him to advocate that aspects of Western education he considered in contradiction to that holy book, such as evolution, the big bang theory of the universe's development, elements of chemistry and geography should be forbidden (Walker, 2012:3). While critical of the government, Yusuf was involved in official efforts to introduce and implement Sharia in several northern states in the early 2000s. The failure to achieve this fully helps explain Muslim youths' anger with government "deception" and "insincerity" and the call for an authentic Islamist revolution. Most accounts date the beginning of BH - Jama'tu Ahlis Sunna Lidda'awati wal-Jihad (People Committed to the Propagation of the Prophet's Teachings and Jihad) its formal Arabic - to 2002, when it began to attract official attention.

Falola and Heaton (2008: 206) hold that with the surge of Islamic reform groups in the north that share broadly common stated goals of promoting a purist vision of Islam based on Sharia; eradicating heretical innovations, and for many establishing an Islamic state in the north, generally political debate was legalistic interpretations of religious texts. Although the traditional Sufi orders remain predominant, the Jama'at Izalat al-Bida wa Iqamat al-Sunnah (Society for the Eradication of Evil Innovations and the Reestablishment of the Sunna), better known as the Izala Movement, in particular contributed to a general religious revival and a much greater public and political role for Islam. It was joined by several other reform movements, including the Muslim Students Society of Nigeria (MSS), widely regarded as a platform for young radical preachers, and the Islamic Movement of Nigeria, a more radical offshoot of the MSS better known as the Muslim Brotherhood, or Zakzaky, after its leader (Zenn, 2013:13-18). A smaller, but far more radical movement emerged around the same time as Izala. Mohammed Marwa, nicknamed Maitatsine (meaning "the one who curses" in Hausa), a young preacher from northern Cameroon, took an aggressive stance against Western influence, refusing to accept the legitimacy of secular authorities. As his following swelled during the 1970s with unemployed urban youth, relations with the police deteriorated. In December 1980 a confrontation at an open-air rally in Kano sparked massive, weeks-long rioting, leaving many hundreds dead and spreading to other states. Marwa died in the initial riots, but pockets of violence continued for several years (International Crisis Group, 2014:3).

We also showed that a similar group appeared in the North East, initially referred to as the Yusufiyya or Nigerian Taliban and later as BH. Comparable to the Maitatsine group, but more threatening, BH was founded and led by Mohammed Yusuf, with the aim of establishing Sharia Law and eliminate westernization in Nigeria. This isolated religious community based on Salafisism and social Talibanism pedestal in Kanamma village in Yobe State attracted a handful of followers from poor Muslim communities of Niger, Chad and Cameroon, estimated between a few hundred and 10,000 after his establishment of a complex and religious school with a Jihadist intension. In fact, denouncing police and state corruption, the strength of this sect grew as it used its political consideration within the government to dictate its pace. The pace being the creation of a strict Islamic state in the north and the strict adherence to the Quran and the Hadith (sayings of the Prophet Mohammed), and their interpretation as sanctioned by Ibn Taymiyyah (the preferred scholar of Mohammed Yusuf, the sect's leader). Like the majority of Salafi organizations, it is most concerned about what it means to be a good Muslim, defined by observance of the prescriptions of the faith, notably the categorical distinction between what is licit (halal) and what is forbidden (haram) (International Crisis Group, 2014:9). This "good Muslim" opinion soon influenced the extension of the Islamic state to the creation of Caliphate to encompass the northern parts of Nigeria, Cameroon and southern part of Niger, due to their ethnic and cultural intertwine. But Bakari (2013:13) claims that the "Caliphate creation was not due to ethnic or cultural linkages, but provoked by the recent discovery of huge oil deposit, and thus such a state and its control would be the most interesting and enriching venture ever made". 
Stretching the Hypothetically "Unstretchable" Check against Boko Haram Terrorist Recalcitrance around the Lake Chad Basin Area: A Direct Payoff for Staking the State and State Interest on the Platter of Personal Attention

As a matter of fact, the group's multi-nationalistic character has for long exerted influence in Nigeria, meanwhile retaining an arsenal of weapons for what it considered "defense." For more than a decade later, its activities provoked a sight of one of the world's most recent but ruthless, violent, and aggressive terrorist organizations with a clearly offensive strategy, even though with more an inwards focus. The turning point in this group's rise to full-fledged militancy occurred in July 2009 after a four-day battle with Nigerian government forces in Bauchi, Kano, Yobe and Borno provinces, which resulted in a dead-toll of 800 of its members, including its leader Mohammed Yusuf. The avenging of his death, notoriously video-recorded, widely became the principal rallying point for $\mathrm{BH}$ after reconstituting itself in September 2010 (www.usip.org: 2010:1-6).

We also show - from BBC News of 3 January 2015 and Human Right Watch report of 15 July 2014 that with the change of leadership from Yusuf, a preacher, to the more radical and violent Abubakr Shekau in 2010, the latter tied BH to the international jihadi movement in his statements by adopting anti-American rhetoric and showing support for jihadists in Algeria, Yemen, Somalia and Iraq. BH also stepped up attacks on the Nigerian population, targeting police stations, churches, schools, media houses and state institutions and kidnapping individual and groups of person (over 500 men, women and children - including the 276 Chibok school girls in April 2014), and these mostly occurred in north-east, north central and central Nigeria. Between July 2009 and June 2014, over 6,000 civilian were killed in Nigeria, including at least 2,500 in the first half of 2014 With these actions, especially the suicide bombing carried out at the UN headquarters in Abuja, a more critical international attention was activated thereto. This attention was also at the level of its support. Only for the first six months of 2014, BH carried out 95 attacks that led to the death of over 2,500 civilians, and of which 1,446 occurred in the Borno State. Due to the simple fact of proximity of Nigeria with its neighbours and the permeability of their frontier lines reflected an eventful space, offering to the people of the region great opportunities in terms of human and commodity cross fluidity. This disposition of consistent flow of persons and trade-currents and their multipliers effects gave an easy flow of BH into the Niger, Chad and Cameroon territories. ${ }^{2}$

The entrance of BH in Cameroon was the first split over to a neighboring country. The character of $\mathrm{BH}$ assumed three dominating strategies in this country, namely the abduction of foreigners, theft, open field attacks and recently suicide attacks. As concern hostage taking, the first occurred on 19 February 2013 with the 7 members of the French family of Moulin Fournier. In a video of 21 March, Abubakar Shekau, the movement's chief declares, "We are delighted to affirm that we are in keeping of the 7 French hostages. We are keeping them because the Nigerian and Cameroonian authorities have arrested members of our family. ... We affirm not to release the French hostages when our families are imprisoned. . . ." He maintained that the force was not only to liberate these "family members," but they were ready to defend themselves by the use of force. At any time even the opportunity (BIR, Alpha operation- Cameroon, Maroua video collection, 2015). But after serious negotiations of the Cameroon government via some local personalities, the French family was liberated on 19 April 2013. In the same light, on the night of 13 and 14 November 2013, Georges Vandenbeusch, a 42-year-old French Catholic priest was abducted at Nguetchewe, a Cameroon Far North Region locality, but was also released on 31 December 2013 after serious negotiations between the Cameroon government and $\mathrm{BH}$ elements.

In the night of 4 to 5 April 2014, at Tchère some 20 kilometers from Maroua, the regional headquarters, two Italian priests Giampaolo Marta and Gianantonio Allegri, and a Canadian nun, Gilberte Bussier were also kidnapped by armed men. But these religious elements were finally released on 31 May and 1 June 2014 following a crucial negotiation with BH elements. Also, on 7 October 2014, more than 2 girls were kidnapped at Ouzda-Vreket, Mozogo (Mayo Tsanaga Division) $\left(\mathrm{BIR}^{3}\right.$, Alpha operation- Cameroon, Maroua archives, 2015). At Dangawa et Goudouzou, around

\footnotetext{
${ }^{2}$ For the details of the BH aggressiveness in Nigeria and Cameroon, see Funteh and Azieh, 2015.

3 The BIR was formed in 1999 as the Bataillon Léger d'Intervention (BLI), a special intervention force designed to eliminate foreign rebels, bandits and deserters (the "coupeurs de routes") who were destroying the security of Cameroon's Northern provinces through cattle rustling, abductions, murder and highway robbery. As part of military reforms carried out in Cameroon in 2001, the unit took on its current BIR designation. BIR officers are
} 
Stretching the Hypothetically "Unstretchable" Check against Boko Haram Terrorist Recalcitrance around the Lake Chad Basin Area: A Direct Payoff for Staking the State and State Interest on the Platter of Personal Attention

Mora in the Mayo Sava area, on 7 May 2014, BH incursion in 10 villages left serious death-toll and the kidnap of 2 rich glaziers as well. On the night of 16 and 17 May 2014, BH came along with 5 four-well drive vehicles and attacked the camp of Chinese road constructors at Waza of the Logone and Chari division, killed 1 Chinese and abducted 10, took way 10 pick-up vehicles and explosives (BIR, Alpha operation- Cameroon, Maroua video collection, 2015).

This attack occurred during Head of States' Paris summit against this sect in May. From information collected from BH combatants imprisoned in Cameroon, this attack was to mobility facility and future attacks. It was also hoped that Cameroon would be under pressure to negotiate for the release of these foreigners, and in doing so, the release of their combatants in the Cameroon prisons would then be a non negotiable condition; not forgetting the benefit they must have of made from the ransom to be given by the Cameroon in the process. Such benefits, especially the acquisition of guns and explosives, guided the attack of the police post at Goulfey in Logone Chari (1 May 2014) by 6 heavily armed BH members during which the only police on guard with 10 other persons were severely wounded. Four days after, the Gendarmerie Brigade of Kousseri was also attacked, which resulted in a death and the injury of many. ${ }^{4}$ Here, the post was looted of arms and vehicles (BIR, Alpha intelligence report, Maroua, 2014).

But before the release of the Chinese on 11 October 2014, BH captured 17 Cameroonians as prisoners when they attacked and ransacked Kolofata, a Kanuri group, on 27 July 2014. According to intelligence report, the Vice-prime Minister Ahmadou Ali, a member of this group, was the target. If captured, BH would have compelled the Cameroon government to negotiate at an exorbitant price, but fortunately for him, he was rather in Maroua. But his wife was regrettably kidnapped in the process but was later on released (BIR, Alpha intelligence report, Maroua, 2014). This just came after a German was abducted at Gombi, in the Adamawa state by a band of armed men on 16 July 2014. BH declared all these hostages on 31 October. The German was released on 21 January and so too was the Ali's wife, and Cameroon government claimed this was the result of a special military operation by Cameroon and her allies (BIR, Alpha intelligence report, Maroua, 2015). But many Cameroonians think it was not the case. It was surely done through the usual negotiation process.

Whatever, on 2 March 2014 at Fotokol following the serious BH slaughter of the inhabitants, the Cameroon army responded in a prompt way. This was the first time both forces met in open battle. This action made the government to reconsider its take on $\mathrm{BH}$ as it sent the Alpha Operation of the BIR, notably Emergence II, to protect the Far North region and its environs against the incursions of $\mathrm{BH}$. It was in this light that this operation launched a series of forceful attacks on BH, like Fotokol (a sit of several battles), Tourou on 7 June, Bargaram on 24 and 25 July, Amchidé and Limani on 15 and 16 October, Amchidé on 17 December, Achigachia on 29 December 2014, and Kolofata on 12 January 2015. These attacks were both on the hunt for BH as well as an open field-combat response to their actions as they constantly attacked the Cameroon military field-established camps. When I got to villages like Amchidé, Fotokol and Kolofata, they had almost been wiped-out by BH, as more than 60 percent of the inhabitants were killed and their houses completely burnt down. This brought a complete halt of both public and private life. The survivors were displaced to Mora. In place like Amchide and Limani former trans-border trade seats, became ghost villages and of course a huge blow on the economy of the area. ${ }^{5}$ Generally speaking BH caused closed to 15,000 displaced persons and the death of thousands in the Far Northern region of the country.

As a matter of fact, all through 2014, BH made regular forays into Cameroon, particularly along the borders of the two most northern regions, applied light-armed force in villages and took away huge

selected from the graduates of the Ecole Militaire Interarmées in Yaoundé. Recruits were sent to the different battalions created and spread all over the considered trouble spots in the country.

4 Group interview with some inhabitants of Kousseri and Goulfey on 13 May and 20 May 2014; I must thank the Joseph Nouma, Colonial of the Alpha Operation in Far North Cameroon for the military assistance he gave to me during the collection of data for this paper, without which having access to the areas and convincing people to share their experiences with me could have been futile.

5 For the Economic consequences of BH on the Cameroon-Nigeria borderlands, see Funteh (2015 c: 30-48). 
Stretching the Hypothetically "Unstretchable" Check against Boko Haram Terrorist Recalcitrance around the Lake Chad Basin Area: A Direct Payoff for Staking the State and State Interest on the Platter of Personal Attention

amount of cattle, fowls, cereals and foodstuff. The constancy of these acts, other reasons, was aimed at feeding the young jihadists camps being built in the region by 45 instructors, incubating 84 young recruits (between the ages of 7 and 15). These camps were dismantled on 20 December 2014 by the BIR. Such BIR interventions became more upright and sleepless with increasing present of BH in region, and specifically in 4 of the division that made up the Far North Region of Cameroon, victimized by the attacks and leaving behind unprecedented human and material damage on both sides which included 98 military personnel and close to a thousand civilians and two thousand the displaced persons. By 2015, the death toll had risen to untold proportion and the number of displace in the northern part of Cameroon was also enormous. Part of this was the brutal hunting down of $\mathrm{BH}$, seizure of their means of mobility (cars and motorcycles) and very heavy weaponry, and stepping up of intelligence activities. But because the response of the Cameroonian army did not seemed to be providing the desired outcome, the President of the Republic, Paul Biya appealed for international support. With the presence of this international intervention in the region, the $\mathrm{BH}$ decided to change tactics. This varied from the placement of mines and explosives on major circulation trends, which destroyed a number of military armored cars and killed a good number of solders to the utilization of suicide bombers. ${ }^{6}$ Their target, which was public areas, had given them the desired results in Nigeria and thus using them elsewhere was definitely going to be profitable as well.

The suicide bomber and bomb planting strategies were used in Niger but for the vigilance of the state security intelligence. In fact, the aftermath of the 2012 Malian uprising and Nigeria's implementation of the 2013 State of Emergency to crack down on BH, alongside other displaced persons entered Niger, and not long in southern Niger, BH plotted to bomb public places was foiled. The Nigerien authorities arrested 15 members in Diffa in 2012, who had planning to attack the local military garrison through bomb planting and suicide bombers. On 14 October 2012, BH kidnapped 5 Nigeriens and a Chadian in Dakoro (Vanguard, 15 October 2012). In 2014, the Nigerien government arrested $20 \mathrm{BH}$ members in Diffa and Zinder and foiled the plot of attacking a series of markets. Niger's army Chief General Seyni Garba said his country avoided a "bloodbath." But such bloodbath could not be avoided by an army patrol in Diffa who ran into the waiting arms of the $\mathrm{BH}$ and their mines. However, the 12 culprits were arrested and brought to justice three days after.

In Chad the value of abduction, gun-down and suicide bombing strategies were aptly employed by the BH. The Premium Times (12 September 2014) recorded, based on Chadian Army sources and communications obtained between Nigerian field officers and the Nigerian military, arraigns Modu Sheriff, former Borno State governor, for sponsoring the BH. That he harboured and trained BH militants in Abéché, Chad. IRINnews (as cited by Sagir Musa, Vanguard, 11 May 2014 adds that arms intended for the BH were trafficked from Lybia and Sudan and some even reached the Central African Republic. As this was going on, the Chadian President Idriss Déby raised the alarm about instability in the Lake Chad basin and about "the permanent threat" from $\mathrm{BH}$ and its foreign connections, and as a results sent troops to the Nigerian border with the of France that resulted in Operation Barkhane in August 2014 a regional initiative with headquartered in N'Djamena (Marcelle Balt, 2014). When this happened, Chad increased the chances of being a target by the BH. This was true as on 6 August 2014, the BH crossed into Chad gunned down 6 Nigerians (who had fled an attack the past weeks in Kirenowa, a Nigerian border town to Cameroon) in Dubuwa village. In a more brazen attempt to enter Chadian territory, on 16 August 2014, in an attempt to entre Chad, the BH over 100 young men in Doron Baga fishing village in Nigeria near Lake Chad, loaded them speed boats to an island under Chadian control, but were rescued by the Chadian security officials. They had intercepted a convoy of buses, rescuing 85 hostages and arresting the six men accompanying them (Sahara Reporters, 15 August 2014; Aminu Abubakar, 17 August 2014). In fact, after May 2014 Paris Summit for Security in Nigeria in which President Déby agreed to launch a "total war" against the $\mathrm{BH}$, an audiotape surfaced on Alwihda Info that threatened Chad for its participation in the military coalition (Abu Adil, 23 May 2014). The voice on the tape which was identified as a Chadian threatened President Déby and promised to attack the capital, N'Djamena (Alwihda Info, 5 June

\footnotetext{
6 Generally speaking, the explosives' effects were in a radius of 50-60 meters (yards). And according to Alpha Intelligence Report (2015), meanwhile in most cases the explosives were detonated by the bombers themselves, some evidence from the vest on the child bombers suggest that the bombs could have been set off remotely.
} 
Stretching the Hypothetically "Unstretchable" Check against Boko Haram Terrorist Recalcitrance around the Lake Chad Basin Area: A Direct Payoff for Staking the State and State Interest on the Platter of Personal Attention

2014). In response, Chad deployed security forces in N'Djamena and the French Embassy installed protective measures, but the attack still took place.

So as these were going on, the leaders of the region decided to create the Multi-National Task Force (MNTF) and the Chadian forces' impressive crush of BH on 29 and 30 January 2015 was the beginning of that cherished international response, which Paul Biya had desired. This 8,700-strong regional force of troops from Benin, Cameroon, Chad, Niger, and Nigeria had been on its hills to have the job which individual states were putting up completed. As this was unfolding, the Cameroon population, gripped with $\mathrm{BH}$ fever, also was responding in support of their soldiers on the field (BIR Intelligence Report 2015, Maroua).

Such national and international response was gradually yielding fruits when $\mathrm{BH}$ changed tactics on the Cameroon soil. From the open field confrontation, they adopted the planting of mines on and around drivable roads, which did not prove minimal in hurting the efforts of the Cameroon army and the MNTF. The planting of mines was chained-up with suicide attacks in public places, like mosques, markets and drinking spots. Between late 2015 and early 2016, suicide-bombing increasing occurred in the region. This was meant to have the desired effect, and was carried out mostly by teenage girls between the ages of 12 and 25 (although adult men and women were sometimes utilized valuably for the purpose) who wear handcrafted automated bombs ready to explode in these very populated areas. However, in some cases, like in Mémé, between Maroua and Mora, two attackers detonated explosives hidden in drinking water supplies in the village and killed 12 and injured 59. Similar actions were repeated in Mora, killing more than 24 persons, in Bodo killing more than 38 persons. In Kolofata, a young boy arrived in the village by foot and behaving suspiciously and when the locals tried to intercept him, he ran towards the mosque and set off the explosives he possessed to kill 12 people. This was the second deadly blast to hit the Kolofata district during morning prayers. In Nguetchewe, 11 worshippers were also killed in a mosque. In fact, this was a reflection of what happened in Fotokol where more than 13 persons lost their lives (including 6 Cameroon solders standing guard) following a suicide bomb explosion. More so, two suicide bombers also entered the army-camp at Kerawa and killed over 19 persons (Ibid.). Nonetheless, the introduction of suicide bombing in this part of the country began in Maroua. Here, two suicide bombings occurred at the central market, which killed close to 20 peoples and injured 38 others. Some few days later at the Quartier bong vert, another one occurred that killed closed to 13 persons and wounded 10. These attacks were all carried out by three girls of ages between 13 and 24, who all died alongside the victims.

Some of these girls were sex slaves of the group, drugged and psychologically damaged, and therefore remained vulnerable. They were used for this purpose because they are thought less likely to arouse suspicion, although that opinion has changed now. Cameroonian officials said the first explosion occurred at a morning market on Thursday. The second blast happened 200 meters away near a camp housing infantry troops. The number of people injured stood at 143 (From author's observation and BIR, Alpha intelligence report, Maroua, 2016). The infiltration of BH into the population, its change of tactics and the effect of its suicide bombing, prompted the government to multiply the police and gendarmerie contingents to this part of the country, which ransack quarters, houses and cars to find infiltrated or infiltrating suspects and apply the law. But these efforts were still not sufficient to provide the desired results. The most workable tactics to bringing to book the suspects would be to valorize the community policing tactics that had been in existence in this part of Cameroon (like elsewhere, since the pre-colonial times) to complement the public forces in sustaining a thorough fight and eradication of the $\mathrm{BH}$ phenomenon in the region. We (Funteh and Azieh, 2015) indicated that BH's adoption of suicide bombings was an indication that they have lost the conventional military battle against the Cameroonian forces. The Cameroon population in Mora to the border towns and villages with Nigeria until December 2016 continued to experience pockets of suicide attacks in public places. It is worthy to note that the past 7 insecurity ruthless years in the Lake Chad Basin area perpetrated, in the main, by the $\mathrm{BH}$ insurgencies killed over 30, 000, displaced over 2,5 million with immeasurable tangible and intangible political, economic and socio-cultural corollaries. No wonder, the Global Terrorism Index (2015) rated the BH as the world's deadliest terror group. 
Stretching the Hypothetically "Unstretchable" Check against Boko Haram Terrorist Recalcitrance around the Lake Chad Basin Area: A Direct Payoff for Staking the State and State Interest on the Platter of Personal Attention

During the May Paris Summit, it was clear that the head of states of the region were exhausted to fight the BH on an individual account. They cried out for help through a regional joint effort and/or assistance from international friends. It all started with Chad coming to help Cameroon and Nigeria in their struggle against the BH. Emmanuel Tumanjong (2015) announced that following an official visit of the the Chadian president to Yaounde, Cameroon, both governments agreed working together. It resulted to a joint Chad-Cameroon force, stationed in Maroua. Combatants of both countries carried out collective aggression against the $\mathrm{BH}$. This only came to fruition after the terrorists seized a military base in Nigeria, just across Lake Chad. The capture of this base in Baga saw the death of many civilians, 3,700 houses burnt down and close to 200 refugees killed. The Baga rampage pushed Chad to become fully involved for fear that Chad could also be attacked, which later happened as explained. But such intervention could be more reliable and profitable for the region if a bigger and more engaging force was formed. This led to the creation of the Multinational Joint Task Force.

The transnational efforts to combat crimes in the region predate the emergence of the terrorist movement. The Multinational Task Force (MNJTF) between Nigeria, Chad and Niger was set up in 1988 in order to combat transnational crimes in the Lake Chad region. But most dormant until 2012 when it was reactivated in order to stand against the $\mathrm{BH}$ and its transnational insurgencies. Thus the Paris Summit of May 2014 brought together the heads of states of Benin, Chad, Cameroon, Niger, Nigeria and France, and representatives of the US, UK and EU who decided to enhance regional cooperation against the $\mathrm{BH}$ by means of coordinated patrols and border surveillance, pooling intelligence and exchanging relevant information. Thus, in October 2014, the Lake Chad Basin Commission (LCBC) members (Cameroon, Chad, Niger, and Nigeria) and Benin decided to improve their cooperation against the common enemy. It was also agreed that the African Union and UN to establish the appropriate legal framework for the cross border military operations.

The African Union (AU) Peace and Security Council authorized a revisited Multinational Joint Task Force (MNJTF) against BH at its 29 January meeting, ahead of the summit of the AU Assembly held in Addis Ababa on 30 and 31 January 2015. Although these developments were largely interpreted as a shift in Nigeria's foreign and security policy, a closer look at the situation indicates that Abuja's position has not deviated that much. Nigeria remained reluctant to allow foreign intervention on its territory, and still aims to retain ownership and exert its leadership in any attempt to combat the terrorist group. But the failure to ascertain this role prompted the Chadian troops entered Nigeria entered Nigeria from Cameroon and engaged in intense fighting with the militant group in the town of Gamburu- but it was within the framework of a bilateral military agreement, not a multinational force. As for the AU-authorised MNJTF, it would not be deployed in Nigeria, but along Nigeria's outside borders within neighbouring countries, with the aim of containing the terrorist group's regional expansion (Ibid.).

Instead, with "contingents deployed within their national territory," the MNJTF was mandated to conduct operations aimed at preventing the expansion of $\mathrm{BH}$, as well as other terrorist groups and eliminating their presence. It also aimed at facilitating the conduct of joint/simultaneous/coordinated patrols and other types of operations at the borders of the affected countries. It was also agreed that the 8 700-strong forces headquartered in N'Djamena, Chad, would be authorized to exercise a "right of hot pursuit" on Nigerian soil. Agreeing on a concept of operations was considered a crucial step in obtaining the United Nations' (UN) legitimization. Of course the actions of this force, coupled with the help of the US, Russia, France and China on overt and disclosed levels in terms of technical and material contributions helped to check the $\mathrm{BH}$ transnational campaigns. But what is very interesting is that despite all these sophisticated man and technical prioress of these big war experienced nations, bringing the $\mathrm{BH}$ to a complete subjection has not yet been realized; even though it aggressiveness has been tremendously reduced for the past months. It is a fact that the sect for the past seven years, have made uncountable offensives and even when fought back, they change tactics and try to regain good grounds. This fight against terrorism has unexpectedly been prolonged. However substantial are the attributions of many scholars to explain the reasons for fighting duration, which according to them centers on the asymmetrical nature of the fight, this paper understands it differently. Its inclination is the preference of personal attention against state interest in the issue, the focus of the forerunning analyses. 
Stretching the Hypothetically "Unstretchable" Check against Boko Haram Terrorist Recalcitrance around the Lake Chad Basin Area: A Direct Payoff for Staking the State and State Interest on the Platter of Personal Attention

\section{Personal Attention: State And Collective Effort Betrayal In The Fight Against THE BH}

What I refer to personal attention here is simply the tangible and intangible benefits the local population (civilians and the military alike) had to gain and went out to gain in support of the $\mathrm{BH}$ despite the stringent stands the states had vis-a-vis the sect and its massacres in the region. Consequently, when the individual state or the joint endeavour was making quick process in the struggle, such intensions and/or actions quickly weakened, slowed down or broke down whole process. It is perhaps important to indicate here that the strength this terrorist group manifested showed that they had huge support from other sources to help sustain its being. Such help was both material and financial. It was the value, display and usage of these that many got enticed to either join or help the sect to attain gain objectives at any given time. Sometimes, people were carried away by the illusionary offers the group sold out to them, be them religious, political, economic and even social.

The non resistance of the BH by some locals was the group's ideological marketing. When the group's ideology was disclosed, it did not only found kindness in the eyes of other terrorist organizations, but in the eyes of many in the region. One of the greatest benefits to some people was religious. The group offered the opportunity of being martyrs; that is obtaining salvation from killing and/or dying in the name of Allah. There had been glaring manifestations of this when culprits or suspected members of the group were apprehended and during interrogation sessions openly expressed their willingness to die. They often said in their own words "I got nothing to lose. If you want to kill me, please do, my heaven is waiting for me. I am already seeing heaven." In Maroua at the Police Post at Harde where some of them were caught and detained, their common language was "we have nothing to say, please kill us fast and liberate us from this hard and sinful world." 7 These pronunciations were a show of the desire to die for a spiritual benefit. In some concrete sense, this false preaching or better still indoctrination of the population was smeared by the group's interpretation, amongst other things, of "defiling action" of the Western countries in the Middle East and its related consequences on the growth of Islam and the Muslim world in general; thus it was time to stand at the point of death or die against fighting anything Western in the region. From data gathered from most informants and through the daily declarations of anti-West die-hearts, confirm the emergence of the $\mathrm{BH}$ as a long awaited opportunity to avenge for the "atrocities" of the West against the Muslim community all over the world. It was common to hear many of them talk of sustaining the group and its actions as the right thing to do for spiritual and emotional satisfaction.

No wonder that the desire to pursue this illusionary factor sold by the BH gained grounds and support from other Islamic fundamentalist and terrorists. According to the International Crisis Group (2014:23-26), the BH members have links with a number of radical groups, including al-Qaeda and the Afghan Taliban. In the aftermath of their June 2009 insurrection, 30 members were arrested in Adamawa state and returned to Maiduguri, where they reportedly admitted having received training in Afghanistan. It maintains that between 2000 and 2002, Osama Bin Laden issued two audio messages calling on Nigerian Muslims to wage jihad and establish an Islamic state. His interest dated from his 1992-1996 stay in Sudan, where he reportedly met Mohammed Ali. He was a Nigerian from Maiduguri studying at the Islamic University in Khartoum who later became his disciple and was trained in Afghanistan. Bin Laden asked him to organise a cell in Nigeria with a 300 million naira budget (approximately $\$ 3$ million in 2000). Ali returned home in 2002 and began funding religious activities of Salafi groups that were unaware of the plan. Mohammed Yusuf and his group allegedly were the major beneficiaries. Links appear to be most significant with Ansar Dine ("Supporters of the Faith" in Arabic), AQIM and the MUJAO, an AQIM splinter group.

Many of these groups' leaders and fighters from Mali, Mauritania and Algeria engaged in lucrative criminal business with arms traffickers, narcotics smugglers, kidnappers and human trafficking gangs. Some fighters were trained and armed by the former Libyan strongman, Muammar Qadhafi, to destabilize their home governments. His fall opened many arms depots to local militants. The three

7 Interview with Abdoulaye Garga, 45, Police officer, Harde Police Post, 13 May 2014, Maroua.

International Journal of History and Cultural Studies (IJHCS) 
Stretching the Hypothetically "Unstretchable" Check against Boko Haram Terrorist Recalcitrance around the Lake Chad Basin Area: A Direct Payoff for Staking the State and State Interest on the Platter of Personal Attention

Islamist groups boosted BH. In particular AQIM made its financial resources, military arsenals and training facilities available. During his police interrogation, Yusuf reportedly provided information on the flow of weapons to the sect from, among others, private sources in Niger, Cameroon and Chad. It was also not uncommon for the Alpha operations of the BIR-Maroua, to arrest, interrogate and imprison and/or transfer some commoners as well as rich and political influential personalities in the Far North Region of Cameroon to Yaoundé for sever interrogation accused of participating in helping the $\mathrm{BH}$. The help was either in the form of lodging, financing, arms or recruits, and this arrest occurred only after investigations and house search that sometimes resulted in the discovery of huge amounts of illicit arms. Thus, true, this group did not only depended on international help but got domestic help from their sympathizers and partakers of the course in Cameroon, Nigeria, Niger or Chad. The example of Modu Sheriff in Chad, as earlier discussed is a pointer to the opinion here raised. Also, the Nigerian government accused and arrested some top ranking citizens from the University through the political rank and files for sustaining the sect's ideology and doing all to keep it alive for the sake spiritual satisfaction. In fact, this illusionary proclivity was far stronger than the manifestation of patriotism.

In fact, what was patriotism when the value of brotherhood and the protection of their alike transcended patriotism and international frontiers. Not only based on the religious obligation to stand along with their fellow Muslims, the influence of the dynamism of the transnational ethnic groups and the socio-cultural habits of the local population too did not totally play for the rigorous fights put up for against the $\mathrm{BH}$. The emergence and spread of this terrorist group was facilitated by the overwhelming ethnic links entwined in the region as earlier explained. So when the members of the group hit in a country, it simply followed these blood lines into the same stock in a neighbouring country. And since it was very unlikely for kins and kiths in the region to betray themselves to a stranger (the state or any person out of this blood line, especially the gadamayos) ${ }^{8}$ no matter the circumstances or crime committed, it was certain that the terrorists were protected, and of course had the time to prepare for more consequential hits. This attitude to protect was a socio-cultural value. In fact, most of my informants openly declare that the value to protect any loved person was sustained by the hypocritical behaviour and secretive lifestyle many profess in the region. These behavioral tendencies are often bred favoured by the closet of their housing types, often surrounded by fences that are strictly inaccessible to strangers, except by permission. As a role, and also for the sake of pride, many people were inclined to preserving the secret happenings in their fence, a safe haven for $\mathrm{BH}$ members. More so, people are not so prone to speaking the truth at all the time and/or adopt a pretentious attitude in the face of difficulties or often exaggerate in their declarations. When talking with most of the investigating officers of the BIR, this was the common complaint they put forth especially when they recounted their experiences with the Cameroon population in the Far North region. They insisted that the closeness of most of the inhabitants in this part of the region served for the protection of the culprits against the desires of the states and their collective efforts in the war, and that they were not ready to give that up even for the sake of their defense and state interest.

More importantly, what was even patriotism in the face of huge political and economic gains obtained from supporting the BH. In as much as many locals think that religion sustained the people's love and preference for the sect to the individual and/or collective states efforts against it, the results of my observation and interaction with the peoples in the field for the past 7 years give me the reason to think otherwise. Politically, when the BH orated the extension of the Islamic state to the creation of Caliphate to encompass the northern parts of Nigeria, Cameroon and southern part of Niger, due to their ethnic and cultural intertwine (which Bakari, 2013:13) rather attribute the creation to the recent discovery of huge oil deposit, and thus such a state and its control would be the most interesting and enriching venture ever made), many rich local politicians and businessmen were promised luscious positions and opportunities in the event of the materialization of the new state. Given this, those

8 Gadamayo is a term derived from Fulfude of the region to mean "on the other side of the river". In the Far North Cameroon of Cameroon in particular, all those originated from the southern part of the country are referred to as such. It is often subjective and indicates that such person does not belong or is not worthy to share in the secrets or benefits of the local people. Since most of the military officers sent to counter the BH were not from the region, it was common to find them treated as strangers with its implications. 
Stretching the Hypothetically "Unstretchable" Check against Boko Haram Terrorist Recalcitrance around the Lake Chad Basin Area: A Direct Payoff for Staking the State and State Interest on the Platter of Personal Attention

interested deliberately provided assistance at their deposal or/and made extra exertion to have the $\mathrm{BH}$ succeed in their chase for victory and occupation of the region. This argument is more preferred to explain the reason for high class citizens' involvement in backing the sect, than a mere satisfaction of religious ego - even though it occupies a comfortable space in the "why" BH support behaviour debate.

Also many other personal political gains outweighed the genuine national or international annihilate the terrorists around the region of the Lake Chad Basin. In Nigeria and Cameroon for example, it was not unusual for people to recount at length and with pleasure how some top ranking politicians and members of the government (especially those from areas purported to habour a massive $\mathrm{BH}$ membership for that matter) use the insecurity situation of their respective countries to manipulate their various governments. It is said that they do as to retain their seats, be appointed to higher positions of authority or have their kins and kiths to obtain more political benefit from the incumbent government. Following the discretional powers and the unpredictable characters assumed by the Head of States of the region in relations to the appointment and dismissal of their collaborators, and their stand against any unpleasant situation that may tease the "desired peace and stability" of their countries, all ministers had to play their cards well. The skills to play were not just to remain in the good books of the president, but also to develop strategies, sometimes Machiavellian in themselves, to overawe the president to maintain them or develop schemes to verify their indispensability in the government. They often made their presidents to believe that they and their positions were one of the cures to the $\mathrm{BH}$ palaver. Whether this popular judgment is founded or not, the strong coincidence of experiencing some fierce $\mathrm{BH}$ attacks in particular places with preceding spread of ministerial cabinet shakeups rumors around the Lake Chad Basin area is quite intriguing. May be this was what influenced the Cameroon's President of the National Assembly, Kavaye Gibriel, in 2014 during a session on terrorism declared that the $\mathrm{BH}$ members were amongst them. He knew that these persons would have infiltrated the high ranks of the Cameroon government like was the case in Nigeria, and such could only happen with a "good price".

This "good price" was one fundamental and efficient strategy used by the terrorists. They were ever willing and ever ready to pay huge sums of money for the growth of their membership, increase in the complex network system and to hit the most cherished targets. They of course knew that the people would need and/or wanted the money, and as it was the case many went for this offer. At times, such offers also meant material possessions given to the very willing, open handed and desperate population, its leaders and their recruits. In order to make maximum employment of this technique, and to have their desired influence go across the frontiers, the BH used specific nationals to reach their people. This was to obtain an international character, command and authority. During an interview with some parents of $\mathrm{BH}$ militants from Fotokol, Ibrahim Baba and Aba Mohamadou in Mora, ${ }^{9}$ I was told that the systematic employed of an inclusive leadership form, which meant choosing its leaders from the different countries of the region and empowering them with substantial and pecuniary authority, was the best option to attract followers from their respective countries. This is confirms the well organized and structured nature of the $\mathrm{BH}$, that is designed into the central and local organs. Meanwhile the movement is directed by the 30 members of the Council of Choura, it is a centralized organization with a general coordinator, five advisors among whom are in charge of external operations and the representative of the $\mathrm{BH}$ in Niger, Nigeria and Cameroon. Besides this central structure, the BH disposes of numerous organs within the different North-eastern Nigerian states, in Chad and even on the Cameroon frontier zones. In fact, six groups operate along the Cameroon-Nigeria frontier lines (Funteh and Azieh, 2015).

These leaders were respected and were responsible for the indoctrination and recruitment of fighters. In fact, the recruitment of their members was done among the illiterate or unschooled and even the schooled. Every commander was in charge of recruiting in his action zone and this involved a long procedure that generally commenced with the process of philanthropic and gift-giving gestures to targeted people. After a while, the Islamic sect sent an emissary to galvanize the potential recruits on

9 Interview with Ibrahim Baba, 56 years, trader, Fotokol, 23 June 2016; Interview with Aba Mohamadou, 64, Farmer and cattle breeder, Mora, 25 and 27 June 2016. 
Stretching the Hypothetically "Unstretchable" Check against Boko Haram Terrorist Recalcitrance around the Lake Chad Basin Area: A Direct Payoff for Staking the State and State Interest on the Platter of Personal Attention

the necessity to strictly follow God and motivated them financially for that choice as earlier explained. At this time, there is no forceful but subtle persuasive recruitment. In most of the Kanuri and other borderline villages, it was very easy for the sect to make new recruitments, especially among the idle and uneducated youths who were often exposed to the activities of BH. The recruits were sent and kept at the Zambissa forest, where they were carefully trained; a training that followed strict ideological and military content. Besides, the Zambissa center in itself produced martyrs, priests and suicide bombers often deployed by the leaders of their respective area where and when the needed arose. Amongst some of my informants arose a severe debate about the consistency of some of these militants who clandestinely visited their families and/or friends to keep whatever financial and material gains they received from their ventures. Some of these gains came through village raids from where foodstuffs and cattles were seized and often at times looted. These gains were enormous and as their value rose, people motivated (and successfully too) their family members to join the sect.

The increasing desire to join and to sustain the interest of the sect amidst the stiff measures against it was the events that proceeded Nigerian border closure with its neighbors. Funteh (2015) holds that the federal government of Nigeria sealed its northern borders with its neighbours in an effort to curtail the activities of the BH insurgents on 23 February 2011. This decision to shut was imperative to stop illegal movement in and out of the country, and also that the closure was "meant to effectively reduce the activities of the insurgents. According to the Nigerian Army, BH were carrying out attacks in the north-east of the country, hiding out in under populated regions of neighboring countries such as Cameroon, Chad and Niger. It claimed that this came after the unearthing of a cache of arms, suspected to have been smuggled in from Cameroon to Borno State, Nigeria. The arms included AK47 rifles, pistols, rocket launchers, bombs, and detonating bomb cables. The army claimed that fighters set up bases in sparsely populated areas of its northeastern neighbors Cameroon, Chad and Niger, which were used to flee across the border after staging attacks to avoid military pursuit. Because the closure of this border had a direct effect on the situation of human and goods movement on the borderlines in the Lake Chad basin area, all the youths involved in trans-border commercial beneficial activities got their bread winning activities cut off, and the only means to survive hardship was to yarn to the attractive offers of BH (Intelligence Report of the BIR, 2014, Maroua). These offers included a new motorcycle and money worth 150, $000 \mathrm{~F}$ CFA for joining the group in Cameroon, 300, 000 in Niger and 350,000 in Chad. ${ }^{10}$ The motorcycles were also used on the battlefront. These idle illiterate and jobless youths had no option but to be involved. Some were particularly paid to monitor the movements of the enemy (arms forces) and furnish the leaders with vital information. Each time they made serious moves in the process of the $\mathrm{BH}$ ideology, they were handed a motivational compensation worth 65,000 FCFA and more was promised them in the event of more successful undertakings. With such material and financial enticement, none was ready to denounce the BH for the state which to them offered them nothing.

Some people in the frontiers towns enriched themselves from the BH provisions. They formed a complex network for the transportation of goods and services for the terrorist organization. In maroua, in Cameroon and Diffe in Niger for instance, many car loaders and drivers of big cargo trucks were apprehended for facilitating the transporting arms and food to the sect. Park boys or loaders as they are locally called, in the process of loading foodstuff or building material from Cameroon to Chad or to Nigeria, carefully glided well-disguised packages weaponry in the loads. By telephone, they informed their friends on the details that included the car, matriculation number and the packages involved, who would waylay and most often kill the driver of the vehicle (if not part of the deal) to collect their parcels. In some instances, drivers of such cars loaded foodstuffs and handed them to the $\mathrm{BH}$ at a scheduled point on the road. After every successful delivery, such attitude was hugely

\footnotetext{
10 From an interview conducted with some relatives to BH combatants in Mora, Kolofata and Kerawa, it was gathered that the sum of money varied from country to country due to the following reasons. Cameroonians proved more willing to join the group and gain from it than the Chadians. The latter had known the value and outcome of such wars and the Deby's tide military actions too dissuaded most of them from getting so involved. As a matter of fact, the BH was not so popular in Chad like in Cameroon. Meanwhile the Nigerians on their part were not so courageous and so needed more motivational incentive than the others. More so, since BH was still struggling to have a good grip of Niger, it was but normal to provide a charming package for the youths.
} 
Stretching the Hypothetically "Unstretchable" Check against Boko Haram Terrorist Recalcitrance around the Lake Chad Basin Area: A Direct Payoff for Staking the State and State Interest on the Platter of Personal Attention

compensation with huge sums of money. It was clear from the observation of some truck loaders and drivers in the region that with the advent of the $\mathrm{BH}$, they had an explosion in wealth. Information collected 11 from each of such suspected individual under custody in the Far North region of Cameroon for instance, revealed their possession of at least three beautiful and expensive newly houses, from three to four new cars within a period of one to two years, and the adoption of a very flamboyant lifestyle. They attest their ever unflinching support for the $\mathrm{BH}$ since their change of life is thanks to it.

This flamboyance was also seen amongst some forces of law and order and some vigilance groups in Nigeria and Cameroon as a result of their dubious interactions with the members of the sect, let me desist from saying corrupt interactions. The top military official of the Alpha BIR operation in the Far north region of Cameroon and some members of the Nigerian arm forces taking refuge in the region from serious attacks in northern Nigeria made certain astonishing revelations during my collection of data for this paper. The Alpha element disclosed how some Cameroon soldiers were caught and tried for trying to disclose their aggressive agenda against the BH. This was only for the sake of money. In Nigeria, many of the local arm forces joint the BH as field operators and some other top military officials who joined, preferred to remain in the highest ranks of decision making of the state so as the best tactic of disclosing all state strategies and movements to counter the $\mathrm{BH}$. This information was vital for the progress of the sect's actions in the area. In fact, as it was a common case with some Cameroonian police and gendarmes elements deployed to help sustain the rude fight against the terrorist sect in the major border corridors of the Far North Region, and following the orders given that strict checks be done on all cars and individuals entering into the area, many inhabitants complain of the character of these forces of law and order. They spent more time collecting money from the locals without checking them. When stopped for the check, everybody, even non identifiable individuals were released upon the giving of money. The amount collected was known and ranged from 1000 to 5000 FCFA.12 The fight against the BH was transformed by many as a money-making opportunity. In fact, BIR officers recount their experiences. They complain that in their own words: "while we are busy fighting the BH members who had earlier infiltrated the major towns in the region, our friends of the other forces enjoyably fellowship under their cohesive hands and allow them to enter the town, hence annulling all the cleaning efforts we have put on." Making reference to this cohesiveness was in fact referring to huge sums of money taken from non identifiable individuals. The repercussion was enormous in Maroua and its environs as earlier indicated. Also, following an arête of the Governor of the Region in 2014, announcing a curfew against the circulation of motorcycles in Maroua after $8 \mathrm{pm}$, since this was suspected to be a popular means through which the $\mathrm{BH}$ circulated at night within the town, all legal motorcycle riders at night became a target of extortion. Sometimes during the day, they were stopped and extorted. This extortive attitude continued from one contingent to the next deployed to the region. As a matter of fact, coming to the Far North was an opportunity to enrich themselves. 13 With this in mind, it was obvious that coming to the war zone was accompanied by the wrong motive would not help to shorten the fight against the $\mathrm{BH}$. This was the attitude that provoked the motorcycle riders, especially the motor-taximen in 2014 and 2015 to stage, on a constant bases, strike actions against such harassments, incidents that often provoked urgent solution meetings between the Governor and top military officials of region. Such meetings were named "crises meetings". 14

11 This information was gotten through the interrogation of BH suspects by BIR at their military base at Salack, Maroua on 12 March 2014. These suspects included Ababoukar Garbadi, 57 years, Amidou, Abdoulaye 34 years, on 13 March 2014; Baba Abel, 44 years, on 4 April 2014, Garba Abdoul, 47 years, on 28 Febraury 2015; Ali Halirou, 48 years, on 15 February 2016.

12 Interview conducted with 40 inhabitants (civilians) of Maroua, Mora, Bogo, Amchide from 30 June 2014 to 20 October 2016, within age range of 40 to 60 years of different professional background. Nonetheless, of the 12 law enforcement officers I interviewed in these places, none of them confirmed such allegations. But of the 10 Alpha BIR soldiers with who I shared the allegation confirmed it to be true.

13 Interview with Executives of the Maroua Motor taxi trade Union, Maroua, 23, 14, 15, 16 August 2016; Interview with Djakia Danki, 25 years, Alpha BIR element, Maroua, 9 January 2015; Ousman Djailo, 31 years, Alpha BIR element, Maroua, 8 march 2016.

14 Interview with the Secretayr general at the Governor's office, Maroua, 26 September 2014.

International Journal of History and Cultural Studies (IJHCS) 
Stretching the Hypothetically "Unstretchable" Check against Boko Haram Terrorist Recalcitrance around the Lake Chad Basin Area: A Direct Payoff for Staking the State and State Interest on the Platter of Personal Attention

The presence of top military officials in these "crisis meetings" against such outrageous behavour was imperative not only to correct, caution and sanction their subordinates, but also to make things right on their part. Many of them had gotten involved in dirty transactions for personal gains. When the 7 members of the French family of Moulin Fournier and Georges Vandenbeusch were abducted by Abubakar Shekau and serious negotiations for their release was done between the Cameroon government and the BH elements via some local personalities. Some of these local personalities comprised the top ranking police officers, the traditional authorities and others. The negotiation entailed the payment of huge financial ransom for their release. There exist popular notion amongst my informants and many locals in the Far North Region of Cameroon that some of these personnel withheld part of the money designated for the purpose. To ascertain the truism of this notion is very tempting when these people talk of an amount close to 4 million FCFA found in the keeping of the Regional Superintendent of Police (Public Security) and his calling to Yaoundé after investigations allegedly proved a reliable connection between the money found and that of the ransom. No wonder, all top security personalities serving in this region were transferred to other regions of the country with some facing disciplinary sanctions. This measure of the state against these dishonest individuals was important for the liability of a good fight against the terrorist sect, which through, Shekau in one of his propaganda tapes in 2014 accused the Cameroonian President for being a man of "double tough," and one of the crimes committed against committed against the group to earn a severe attack. These attacks followed soon after this speech made in Kanuri, Hausa and Arabic, with their multiple effects in the region. After talking with a few Hausa and Kanuri fellows in Kolofata and Amchide on their take on the "double tough" ascription to the president, it was gathered that this term resulted from the bridge of contract between the $\mathrm{BH}$ and the government. The totality of the ransom money designated for the release of the hostages was not paid; implying that the government promised something and did something else. In fact, the holders of the information on the negotiation deal believe the nonpayment of the totality of the sum agreed during the negotiation accounted for the duration of the release of the hostages and the serious attacks Cameroon suffered in 2014.

More so, when in May 2014 the police post at Goulfey in Logone Chari and the Gendarmerie Brigade of Kousseri were attacked, the origin of these attacks were attributed to the personal desires of some police and Gendarme officers. It is alleged that these institutions caught and preserved elements of the sect in their respective post. Instead of handing them to the BIR or send them forward to the right quarters for inquires, they delayed doing so, but rather asked for negotiation with the BH. Negotiation here simply meant that the BH would covertly bring the sum of 20 million FCFA to have the detainees released. The sect bargained for 10 million, and after long and serious talking they all agreed on the payment of the sum of 4 million for the release. The duration of the talk seemed the best process of "good business" in the eyes of the forces of law and order, but it was just time enough for the elements of the group to prepare and hit these public institutions. The night of the arrangement fulfillment, this post and the Brigade were acutely hit resulting in looting of arms, vehicles and the death and injury of many. 15 These arms and vehicles unquestionably reinforced the might and the resilient dispositions of the terrorists for more deadly offensives.

As a matter of fact, the BH members knew the attitude of these people and capitalized on it to infiltrate themselves deeper into the fabrics of the society, control and movements of the army and of course get to their targets easily. One of such peoples used were some members of the traditional authorities and the vigilante groups. When it was certain that conventional approaches to fight terrorism the Lake Chad Basin would be more effective with the utilization of local realities, the implication of traditional authorities and community policing (vigilante groups), and the states decided to use them. They mastered their people, the environment and could better help the state in the fight against the terrorists. Unfortunately, intensive investigations proved that while some of these custodians of the land and state auxiliaries were truly committed to seeing into it that terrorism be eradicated in the area, others were responsible for sustaining the sect. They were the brain behind the infiltration and advancement of terrorists in the region. In as such as some made huge gains from the

15 This information was gathered from an interview conducted with 23 people in Goulfey in Logone Chari, Kousseri from 24 October to 2 November 2016. 
Stretching the Hypothetically "Unstretchable" Check against Boko Haram Terrorist Recalcitrance around the Lake Chad Basin Area: A Direct Payoff for Staking the State and State Interest on the Platter of Personal Attention

middleman position during the liberation-of-the-hostages-negotiations course, others blatantly remained accomplices in the $\mathrm{BH}$ moves. They provided them shelter and protection, provisions and state counter strategies information (they received during security meetings often organized in the region comprising of state representatives from Yaoundé, the regional civil administrators, traditional authorities and security officers). And all this was for the sake of the huge economic benefits they received from the $\mathrm{BH}$. It was for this reason amongst others why some jahoros in the context of Cameroon were apprehended by the BIR. The guilty ones were subjected to the course of the law while the no guilty released. ${ }^{16}$ It is important to indicate here that when member states of the region decided to encourage the creation of more vigilante groups or empower existing ones (as it was the tradition of the peoples of the region) in 2013 and 2015 with the necessary weapons to stand up against the members of the sect, some rather use their membership in vigilante groups to enrich themselves spying for $\mathrm{BH}$. They constantly provided them $(\mathrm{BH})$ with vital information on the movement of the arm forces, the save places to hide and how very important decision taken to counter them in exchange for no small payments. ${ }^{17}$ Whatever, when it was announced, for instance in Cameroon, that community policing had become vital in the fight against the $\mathrm{BH}$ and that the state would be providing them with both financial and material support, every community multiplied its vigilante groups. In the small locality of Mokolo in the Far North of Cameroon for instance, closed to 50 new groups were born, which the sub-divisional administrator transformed such into his money making mechanism. Whenever the state sent money for the upkeep of these groups, he unliterary decided to rather buy and distribute to them bags of rice and to keep the money for himself, hence helping the advancement of the fight against the terrorism in no good way. The situation became critical to the point that close to 30 groups were dissolved for lack of work motivation and equipment, which accounted for the series of the attacks that occurred in the Division of Mayo Tchanaga. Nonetheless, the administrator was later granted a punitive transfer to the Eastern region of the republic. ${ }^{18}$ Could the members of the dissolved vigilante groups be accused of not being patriotic? The BH in their advancements realized the most people of the area were easily coerced personal forces of interest, and could also easily betray their respective countries on the account.

\section{CONClusion}

This paper was an attempt to understand how personal interests surpassed patriotic feelings and its multipliers effect in the fight against the BH insurgencies in the region of the Lake Chad Basin. The $\mathrm{BH}$ for the past 7 years has served as the major threat to peace and the stability of the entire region with ever growing violence and attacks on security forces, civilians, media houses, as well as international bodies. With the increased number of cadres, improved and sophisticated weaponry, suicide bombings and well organized guerrilla tactics, BH's challenge to the individual and collective states' efforts proved more prolonged than expected with severe socio-economic and political ramification on the region. The strength of the group was the peoples' placement of personal attention - illusionary, financial and material profits - before anything else within the ranks of both the soldiers, forces of law and order, civil administration, and the local civilians. The understanding of the existing entwine between individual aggrandizement and the $\mathrm{BH}$ economic and strategic resources over state interest in peace and security pursuit in the region is a fundamental contribution to counter terrorism in region. But how did it get to this point. In fact, the states in the region could not expect otherwise, or better still failed to realize the dissociation of their peripheral populations from national agendas. Many reasons explain this. When a people live in abject poverty, hope is lost and any given opportunity to better its situation becomes the most cherished option without a second though given. In the event of the region's neglect in socio-economic development, the lack of basic development

\footnotetext{
16 Interview with Joseph Nouma, 52 years, Colonial of the Alpha Operation in Far North Cameroon, Maroua, 13 December 2015; Interview with Jibrila Amadou, 57, jahoros, Ouro Lope, Maorua, 23 February 2016.

17 Interview with Joseph Nouma, 52 years, Colonial of the Alpha Operation in Far North Cameroon, Maroua, 13 December 2015; Interview with Jibrila Amadou, 57, jahoros, Ouro Lope, Maorua, 23 February 2016.

18 Information collected from group interviews conducted with four different vigilante groups in Mokolo and Kosa, Mayo Tchanaga Division, from 2-13 December 2016.
} 
Stretching the Hypothetically "Unstretchable" Check against Boko Haram Terrorist Recalcitrance around the Lake Chad Basin Area: A Direct Payoff for Staking the State and State Interest on the Platter of Personal Attention

indices (less than 0.6 development index by 2015), huge gap between citizen's input, wages and salaries, mass unemployment of youths, illiteracy, high corruption and embezzlement of public funds, lack of good governance and equitable distribution of resources, and lack of political will to ameliorate the people's living standards, it was but normal to see that the states failed on their part in keeping right to its obligations. It would have been more efficient, easier and more practical to solicit the true patriotic support of the locals in the fight against the $\mathrm{BH}$, if these conditions were in favour of the people; for the respect of democratic principles and the assurance of resonance human security at all levels is unpatriotically dissuasive by itself. The evolution of the $\mathrm{BH}$ in the region evidently designates a truism of the failure of object use of force military in combating terrorism. Despite the success recorded at the moment in silencing this terrorist group, following the blend of some measure of local collaboration and strict soldierly actions, this present peace disposition might not remain constant for long. The insecurity consonants may rebounce or mutate to assume other forms (banditry high way rubbery and so on) or even lauder terrorist articulation except the political, social, economic and cultural problems of the people are not clearly and intentionally ameliorative handled. If the state keeps its own part of the deal, then the people will obviously keep theirs.

\section{REFERENCES}

[1] Abu Adil, "Boko Haram Menace Le Tchad," Alwihda Info, May 23, 2014. "L'enregistrement de Boko Haram Qui Menace Le Tchad," Alwihda Info, June 5, 2014.

[2] Aminu Abubakar, “Chadian Troops Rescue 85 Nigerian Hostages from Boko Haram,” CNN, August 17, 2014.

[3] "Arms Smuggling to Boko Haram Threatens Cameroon," IRINnews, February 21, 2014.

[4] BIR Intelligence Report 2015, Maroua

[5] BIR, Alpha intelligence report, Maroua, 2014).

[6] BIR, Alpha operation- Cameroon, Maroua video collection, 2015).

[7] “Boko Haram Dumps Kidnapped Doron Baga Villagers around Lake Chad," Sahara Reporters, August 15, 2014.

[8] Davids, D., (2003) the government. Cape Town: Dann Publications.

[9] Davidson, B, (1992), The Blackman's Burden. Africa and the Curse of the Nation State, London, James Currey.

[10] Day, G. and Thompson, A., (2004), Theorizing Nationalism, New York, Pulgrave Macmillan.

[11] "EXCLUSIVE: Secret Intelligence Report Links Ex-Governor Sheriff, Chad President to Boko Haram Sponsorship," Premium Times, September 12, 2014.

[12] Falola, Toyin and Matthew M. Heaton, A History of Nigeriam. London: Cambridge, 2008.

[13] "François Hollande's African Adventures," The Economist, July 19, 2014.

[14] Henk, Dan, 2005, "Humans Security Relevance and Implications," Parametres : US Army College 35(2).

[15] International Crisis Group. "Curbing Violence in Nigeria (II): The Boko Haram Insurgency" Africa Report, No. 216, 3 April 2014.

[16] "L'enregistrement de Boko Haram Qui Menace Le Tchad," Alwihda Info, June 5, 2014.

[17] Lewis, "Niger Fears Contagion from Nigeria's Boko Haram Islamists, Niger Arrests 20 Boko Haram Militants in Suspected Plot," Reuters, February 17, 2014.

[18] Marcelle Balt, "Operation Barkhane Increases French Influence in the Sahel,” RFI, July 22, 2014.

[19] Mark Bolak Funteh (2015 a), "Rethinking Cohesion and Integration Precepts within a Collective Polity in Africa: An Epistemological Hierarchy," in Anatole Fogou et Flora Amabiamina (dir), 2015, Identité, citoyenneté et souveraineté, (Dakar, Diasporas noires):165-189.

[20] (2015 b), "The paradox of the Cameroon-Nigeria interactions: Connecting between the Edges of opportunities/benefits and Quandary" International Journal of Peace and Development Studies Vol. 6, No. 3: $30-48$.

[21] Mark Bolak Funteh and Ndikum Azieh, "The "Boko Haramisation" of Cameroon: A prolonged Night mare for a Sustaining Assemblage," International Journal of Humanities and Cultural Studies Vol. 2 No. 1 (June 2015): 213-238.

[22] McCorquodale, R., and Pangalangan, R., (2001), "Pushing Back the Limitations of Territorial Boundaries," EJIL, Vol. 12. No. 5, pp. 1-16.

[23] Niger: Another Weak Link in the Sahel? (International Crisis Group, September 19, 2013), "Gunmen Kidnap Five Aid Workers, Driver in Niger," Vanguard, October 15, 2012. 
Stretching the Hypothetically "Unstretchable" Check against Boko Haram Terrorist Recalcitrance around the Lake Chad Basin Area: A Direct Payoff for Staking the State and State Interest on the Platter of Personal Attention

[24] Nixon,G., (2000), The Making of States, London, Clapton Books.

[25] Osita, Agbu, (2004), Ethnic militias and the threat to democracy in post-transition Nigeria, Uppsala, Nordiska Afrikainstitutet.

[26] Papp, D. S., (1988) Contemporary International Relations: Frameworks for the Understanding, second edition, New Work; London, Macmillan Publishing Company, Collier Macmillan Publishing.

[27] Raphael Chijioke Njoku, 2002, “An Endless Cycle of Secessionism. Intellectuals and Separatist Movements in Nigeria," In Secession, History and the Social Sciences. Edited by Bruno Coppieters and Michel Huysseune, Brussels, VUB Brussels University Press, p. 249.

[28] Sagir Musa, "How Al-Qaeda, Boko Haram Smuggle Arms into Nigeria," Vanguard, May 11,

[29] Walker, Andrew, "What is Boko Haram?” U.S. Institute of Peace (USIP), June 2012, p. 3.

[30] Zenn, Jacob. "The Islamic Movement and Iranian Intelligence Activities in Nigeria", CTC Sentinel, vol. 6, no. 10, (2013), pp. 13-18.

\section{ORAL SOURCES}

[1] Group interview with some inhabitants of Kousseri and Goulfey on 13 May and 20 May 2014

[2] Interview with Abdoulaye Garga, 45, Police officer, Harde Police Post, 13 May 2014, Maroua.

[3] Interview with Ibrahim Baba, 56 years, trader, Fotokol, 23 June 2016

[4] Interview with Aba Mohamadou, 64, Farmer and cattle breeder, Mora, 25 and 27 June 2016.

[5] Interview conducted with 40 inhabitants (civilians) of Maroua, Mora, Bogo, Amchide from 30 June 2014 to 20 October 2016, within age range of 40 to 60 years of different professional background.

[6] Interview with 12 law enforcement officers, Maroua from 23 April 2015 to 4 September 2016

[7] Interview with Executives of the Maroua Motor taxi trade Union, Maroua, 23, 14, 15, 16 August 2016

[8] Interview with Djakia Danki, 25 years, Alpha BIR element, Maroua, 9 January 2015

[9] Interview with Ousman Djailo, 31 years, Alpha BIR element, Maroua, 8 march 2016.

[10] Interview with the Secretayr general at the Governor's office, Maroua, 26 September 2014.

[11] Interview with 23 people in Goulfey in Logone Chari, Kousseri from 24 October to 2 November 2016.

[12] Interview with Joseph Nouma, 52 years, Colonial of the Alpha Operation in Far North Cameroon, Maroua, 13 December 2015

[13] Interview with Jibrila Amadou, 57, jahoros, Ouro Lope, Maorua, 23 February 2016.

[14] Interview with Jibrila Amadou, 57, jahoros, Ouro Lope, Maorua, 23 February 2016.

[15] Group interviews with four different vigilante groups in Mokolo and Kosa, Mayo Tchanaga Division, from 2-13 December 2016.

[16] Group interview conducted among men, women and youths in Kousseri and Goulfey from 13-15 May and 16-20 May 2014 respectively.

\section{AUTHOR'S BIOGRAPHY}

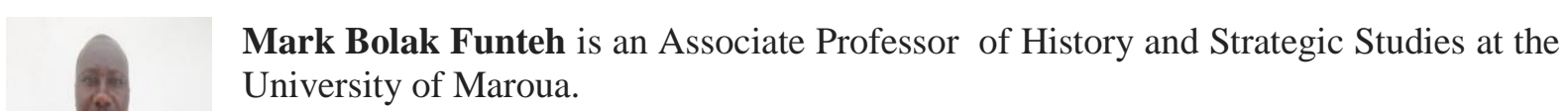

University of Maroua.

Citation: Mark Bolak Funteh. " Stretching the Hypothetically "Unstretchable” Check against Boko Haram Terrorist Recalcitrance around the Lake Chad Basin Area: A Direct Payoff for Staking the State and State Interest on the Platter of Personal Attention'. International Journal of History and Cultural Studies (IJHCS). vol 4, no. 2, 2018, pp. 37-55. doi: DOI: http://dx.doi.org/ 10.20431/2454-7654.0402004.

Copyright: (C) 2018 Authors. This is an open-access article distributed under the terms of the Creative Commons Attribution License, which permits unrestricted use, distribution, and reproduction in any medium, provided the original author and source are credited. 